\title{
PROFIL INDUSTRI MEBEL DI KELURAHAN PASIA NAN TIGO KECAMATAN KOTO TANGAH KOTA PADANG
}

\author{
Rizkamdial $^{1}$, Fitriana Syahar ${ }^{2}$ \\ Program Studi Geografi, \\ Fakultas Ilmu Sosial, Universitas Negeri Padang \\ E-mail : Rizkamdial21@gmail.com
}

\begin{abstract}
Abstrak
Tujuan dari penelitian ini adalah (1) Mempelajari profil industri mebel khusus nya pada faktor produksi (modal, bahan baku dan tenaga kerja). (2) Mengetahui hambatan yang dihadapi oleh industri pada faktor produksi. (3) Mengetahui jangkauan pelayanan dan pemasaran industri mebel.Metode yang digunakan adalah Deskriptif Kuantitatif. Teknik pengumpulan data digunakan ialah kuisioner dan dokumentasi penelitian. Teknik analisis data yang digunakan adalah (1) analisis data dengan persentase (2) analisis jangkauan yaitu buffer pada ArcGis.Hasil penelitian memperlihatkan bahwa Profil industri mebel pada faktor produksi yang dilihat dari segi modal, bahan baku dan tenaga kerja dalam modal industri mebel menyatakan menggunakan modal pribadi. Dalam bahan baku pemilik industri meyatakan bahwa bahan baku yang ada masih mencukupi dalam proses produksi. Dalam tenaga kerja industri mebel menytakan tenaga kerja yang ada sudah tetap dan mahir. Hambatan yang dihadapai oleh industri mebel pada faktor produksi yaitu modal, bahan baku dan tenaga kerja. Dari faktor modal hambatan yang dihadapi oleh pemilik industri mebel yaitu dalam produksi skala besar mereka memerlukan modal tambahan. Dalam bahan baku hambatan yang dihadapi oleh pemilik industri mebel adalah jarak asal bahan baku. Dalam jangkauan pelayanan industri mebel di Kelurahan Pasia Nan Tigo berada di dalam provinsi.

Kata Kunci : Profil, Industri Mebel, Jangkauan Pelayanan
\end{abstract}

Abstract

The purpose of this study are (1) To study the profile of the furniture industry specifically on production factor (capital, raw materials and labor). (2) To Know the obstacles faced by industry in the production factor. (3) To Know the service area and marketing of the furniture industry. The approachof this study was Descriptive Quantitative. In collecting the data, the research used two step: questionnaires and research documentation. The data analysis technique used by the reasearch: (1) data analysis with the percentage (2) analysis of service area, namely buffers in ArcGis. The results of the study show the profile of the furniture industry on the factors of production that have been seen in terms of capital, raw materials and workface, capital stated that it used personal capital. In raw materials, the owner of industry stated that the existing raw materials were still sufficient in the production process. In the furniture industry workforce, the existing workforce is fixed and proficient. The obstacles faced by the furniture industry were production factors, namely capital, raw materials and workfoce. From the capital factor barriers faced by owner of furniture industri, name in large-scale production they require additional capital. In the raw material the obstacles faced by the owners of the furniture industry was the distance from the raw material. Within the service range of the furniture industry in the Pasia Nan Tigo Sub-District within the province.

Keywords: Profile, Furniture Industry, Service Area

\footnotetext{
${ }^{1}$ Mahasiswa Program Studi Geografi

${ }^{2}$ Dosen Jurusan Geografi Fakultas Ilmu Sosial Universitas Negeri Padang
} 


\section{PENDAHULUAN}

Sumber daya alam merupakan suatu bukti nyata akan nikmat tuhan yang diberikan untuk manusia, akan tetapi tidak semua kita mampu melihat lebih cermat suatu potensi sumber daya alam yang bisa dimanfaatkan. Sektor indstri lebih banyak berperan dalam pemanfaatan sumber daya alam ini.

Pentingnya peranan industri dalam pembangunan ekonomi diberbagai negara sudah tidak diragukan lagi. Kontribusi sektor industri terhadap pembangunan ekonomi dari tahun ke tahun menunjukkan kontribusi, (Menurut data dari BPS) pada kuartal pertama tahun 2017 yang mencapai 5,01\% atau di atas pertumbuhan ekonomi pada periode yang sama tahun lalu sebesar $4,92 \%$.

Industri mebel di Kota Padang untuk saat ini belum berkembang dengan pesat, karna industri mebel di kota Padang digolongan kedalam usaha mikro kecil menengah yang dimana terdapat keterbatasan modal, bahan baku serta tenaga kerja, sehingga untung bersaing di skala besar sangat susah karna dituntut untuk lebih produktif serta kreatif.

Menurut Manullang (1991)

Mebel merupakan salah satu produk kayu olahan yang pertumbuhannya amat pesat dalam beberapa dekade terakhir ini adalah produk mebel. Berawal dari pekerjaan rumah tangga, produk mebel kini telah menjadi industri yang cukup besar dengan tingkat penyerapan tenaga kerja terdidik yang tidak sedikit. Untuk menggerakkan suatu jenis industri, maka tenaga kerja sangat dibutuhkan sekali. Tenaga kerja tersebut bukan hanya dapat dilihat dari jumlah tenaga kerja yang diperkerjakan saja akan tetapi lebih mengutamakan keterampilan kerja.

$\begin{array}{rrr}\text { Menurut } & \text { Kasmir } & \text { (2014) } \\ \text { modal adalah } & \text { sesuatu yang }\end{array}$
diperlukan untuk membiayai operasional perusahaan mulai berdiri sampai beroperasi. Modal terdiri dari uang dan tenaga. Pada dasarnya kebutuhan modal untuk melakukan usaha terdiri dari dua jenis yaitu: 1) modal investasi dan modal kerja. Modal investasi digunakan untuk jangka panjang. Biasanya umurnya lebih dari satu tahun. Sementara modal kerja digunakan untuk jangka pendek dan beberapa kali pakai dalam satu kali proses produksi, jangka waktu modal kerja biasanya tidak lebih dari satu tahun.Kebutuhan modal, baik modal investasi maupun modal kerja, dapat dicari dari berbagai sumber dana yang ada, yaitu modal sendiri atau modal pinjaman (modal asing).

Menurut Kasmir (2014) pemasaran adalah usaha untuk memenuhi keinginan dan kebutuhan konsumen melalui penciptaan suatu produk, baik barang maupun jasa yang kemudian dibeli oleh mereka yang memilki kebutuhan melalui suatu pertukaran. 
Menurut Cahyono (1983)

kelemahan dalam pemasaran adalah kekurang sesuaian koordinasi antara produksi dan pemasaran, maksudnya kurang seimbangnya dan kurang terkoordinasinya kedua fungsi penting ini, untuk menyeimbangkan antara produksi dan pemasaran kemungkinan antara : a) memproduksi barang terlalu sedikit sehingga penjualan sulit dilakukan. b) melakukan diversifikasi dengan tergesa-gesa. Hal ini berarti bahwa diperlukan suatu keseimbangan antara keunggulan diversifikasi dengan spesialisasi barang.

Pemasaran jika dilakukan di lingkungan setempat saja tidak akan cepat berkembang dan dikenal oleh konsumen. Untuk itu kita harus memiliki jangkauan layanan pemasaran.

Dalam bukunya "Interpreting The City an Urban Geography", Hartshorn (1980), mengatakan bahwa konsep ambang batas (threshold) dikenalkan oleh Berry dan Garrison yang memiliki hasil spasial dalam gagasan Christaller mengenai jangkauan pelayanan (range of area). Jangkauan (range) adalah wilayah pasar dari suatu barang yang diukur dari jarak tempuh konsumen dalam melakukan perjalanan untuk membeli suatu barang. Jangkauan pelayanan dapat dipengaruhi oleh harga suatu barang, biaya transportasi, kebutuhan akan suatu barang dan selera serta pilihan konsumen.

Jurnal Buana - Volume-3 No-1 2019
Sedangkan Ullman dalam Wahyudi (2008) menyatakan jangkauan pelayanan memiliki batas wilayah tertentu sesuai dengan kemampuan pusat pelayanan. Adapun batas daerah pasarnya, yaitu

1. Batas riil, yaitu batas yang seharusnya dan secara nyata harus dikuasai atau dilayani oleh pusat pelayanan.

2. Batas dalam, yaitu batas wilayah pasar yang lebih jauh dari batas riil.

3. Batas ideal, yaitu jangkauan wilayah pelayanan terjauh.

\section{METODE PENELITIAN}

\section{Waktu dan Tempat Penelitan}

Penelitian ini akan dilakukan

di Kelurahan Pasia Nan Tigo

Kecamatan Koto Tangah Kota Padang.

\section{Sampel}

Berdasarkan populasi penilitain yang telah ditetapkan, maka sampel penelitian ini diambil dengan teknik "Total Sampling" yaitu keseluruhan populasi merangkap sebagai sampel penelitian (Burhan, 2011). Kelurahan Pasia Nan Tigo memiliki 3 industri yang bergerak di bidang industri mebel. Industri ini umumnya mempuyai anggota kurang dari 20 orang.

\section{Teknik Pengumpulan Data}

1. Kuesioner

Kuesioner adalah teknik pengupulan data yang dilakukan dengan cara memberikan seperangat pertanyaan atau pernyataan tertulis kepada responden untuk dijawab. 
2. Dokumentasi

Dokumentasi adalah teknik pengumpulan data dengan cara mengumpulkan atau mencari data yang berkaitan dengan pnelitian baik itu berupa foto, tulisan, dokumen, arsip.

\section{Teknik Analisis Data}

1. Analisis data yang yang digunakan dalam penelitian ini adalah persentase. Dimana data yang diperoleh dari wawancara diolah dengan rumus persentase oleh Sudjiono (2011):

$\mathrm{P}=\mathrm{f} / \mathrm{n} \times 100$

$\mathrm{P}=$ Persentase

$\mathrm{f}=$ Frekuensi

$\mathrm{n}=$ Jumlah Responden

2. Analisis jangkauan pelayanan di lakukan dengan buffer dengan ketentuan yaitu batas riil, batas dalam dan batas ideal. Batas ideal ini ditentukan dengan menentukan jarak terjauh asal konsumen dengan tempat idustri, kemudian melakukan

buffer pada jarak terjauh tersebut sehingga seluruh konsumen berada didalamnya. Batas riil ini ditentukan dengan membagi nilai jarak terjauh asal konsumen dengan jumlah batas yaitu batas kecamatan sehingga didapat jangkauan terdekat antara tempat industri dan konsumen. Sedangkan batas dalam ditentukan dengan mengurangi jarak kedua batas tersebut.

\section{Hasil dan Pembahasan DESKRIPSI DATA}

\section{Industri Mebel Pada Faktor Produksi}

a. Modal

a) Sumber Modal

Dalam hal sumber modal berasal dari pribadi maupun pinjaman berikut data sumber modal dalam tabel 1 dibawah ini :

Tabel 1. Data Sumber Modal Industri Mebel Tahun 2018

\begin{tabular}{|c|c|c|c|}
\hline No & Sumber Modal & $\mathrm{F}$ & $\%$ \\
\hline 1 & Modal Pribadi & 3 & 100 \\
\hline 2 & Modal Pinjaman & 0 & 0 \\
\hline \multicolumn{2}{|r|}{ Jumlah } & 3 & 100 \\
\hline
\end{tabular}

Berdasarkan data yang diperoleh dari 3 responden pada tabel diatas mengenai sumber modal dapat disimpulkan, dalam menjalan industri mebel para pelaku industri menggunakan modal pribadi dalam menjalankan industri. b) Jumlah Modal

Jumlah modal merupakan biaya yang diperlukan untuk menjalankan industri tersebut dalam sekali produksi. Jumlah modal sebagai berikut pada tabel 2 dibawah ini : 
Tabel 2. Jumlah Modal Dalam Sekali Produksi

\begin{tabular}{|c|l|r|}
\hline No & Nama Industri & Jumlah Modal (Rp) \\
\hline 1 & CV. Mekar Baru & 70.000 .000 \\
\hline 2 & Yazira Perabot & 33.000 .000 \\
\hline 3 & CV. Roland Kencana & 67.000 .000 \\
\hline
\end{tabular}

Sumber : Pengolahan Data Tahun 2018

Dari data tabel diatas dapat dilihat jumlah modal rata-rata yang di gunakan dalam sekali produksi berada dibawah Rp. 70.000.000,00. c) Kecukupan Modal

Kecukupan modal ini dilihat dari kebutuhan dalam sekali produksi dalam tabel 3 dibawah ini :

Tabel 3. Data Kecukupan Modal Industri Mebel Tahun 2018

\begin{tabular}{|c|l|r|r|}
\hline No & Kecukupan Modal & \multicolumn{1}{|c|}{ F } & \multicolumn{1}{c|}{$\%$} \\
\hline 1 & Cukup & 2 & 67 \\
\hline 2 & Tidak Cukup & 1 & 33 \\
\hline \multicolumn{2}{|c|}{ Jumlah } & 3 & 100 \\
\hline
\end{tabular}

Sumber : Pengolahan Data Tahun 2018

Berdasarkan hasil wawancara

2 responden menjawab modal yang dimiliki dalam sekali produksi cuku sedangkan 1 responde menjawab tidak cukup.

\section{b. Bahan baku}

a) Daerah Sumber Bahan Baku Dalam hal sumber bahan baku didapat dari daerah dalam provinsi dan luar. Dapat dilihat dalam tabel 4 dibawah ini :

Tabel 4. Daerah Sumber Bahan Baku

\begin{tabular}{|c|l|c|r|}
\hline No & Daerah Sumber Bahan Baku & f & \multicolumn{1}{c|}{$\%$} \\
\hline 1 & Dalam Provinsi & 3 & 100 \\
\hline 2 & Luar Provinsi & 0 & 0 \\
\hline \multicolumn{2}{|c|}{ Jumlah } & 3 & 100 \\
\hline
\end{tabular}

Sumber : Pengolahan Data Tahun 2018

Berdasarkan tabel diatas 3 responden menjawab sumber bahan baku didapat dari dalam provinsi baik bahan baku utama dan bahan baku tambahan. Bahan baku utama dari daerah Kabupaten Padang Pariaman.

b) Ketersedian Bahan Baku Dalam hal ketersedian ahan baku dapat dilihat pada tabel 5 dibawah ini

Tabel 5. Ketersedian Bahan Baku

\begin{tabular}{|c|l|r|r|}
\hline No & Ketersedian Bahan Baku & \multicolumn{1}{|c|}{ F } & \multicolumn{1}{c|}{$\%$} \\
\hline 1 & Tersedia & 3 & 100 \\
\hline 2 & Kurang Tersedia & 0 & 0 \\
\hline 3 & Tidak Tersedia & 0 & 0 \\
\hline \multicolumn{2}{|c|}{ Jumlah } & 5 & 100 \\
\hline
\end{tabular}

Sumber : Pengolahan Data Tahun 2018 
Dari data hasil wawancara dengan pemilik industri pada tabel diatas tentang ketersedian bahan baku untuk produksi mebel dari 3 responden menyatakan ketersedian bahan baku tersedia untuk produksi industri mebel dalam sekali produksi yaitu dalam 2 bulan.

c) Jarak Sumber Bahan Baku dan Biaya Angkut

Dalam hal jarak sumber dan biaya angkut dapat dilihat pada tabel 6 dibawah ini :

Tabel 6. Jarak dan Biaya Angkut Bahan Baku

\begin{tabular}{|c|l|r|r|}
\hline No & $\begin{array}{c}\text { Jarak Sumber Bahan Baku dan Biaya } \\
\text { Angkut }\end{array}$ & F & $\%$ \\
\hline 1 & Kurang Dari 70 Km & 3 & 100 \\
\hline 2 & Lebih 70 Km & 0 & 0 \\
\hline \multicolumn{2}{|c|}{ Jumlah } & 3 & 100 \\
\hline
\end{tabular}

Sumber : Pengolahan Data Tahun 2018

Berdasarkan hasil wawancara dengan responden berdasarkan daerah sumber bahan baku dapat diketahui jarak sumber bahan baku dengan tempat produksi. 3 reponden menjawab jarak sumber bahan baku kurang dari $70 \mathrm{Km}$. Dalam hal biaya angkut bahan baku menuju lokasi industri tidak ada dijelaskan dengan terperinci. Dapat dsimpulkan jarak sumber bahan baku kurang dari 70 $\mathrm{Km}$ dan besaran biaya angkut ditetapkan oleh penyedia bahan baku.

d) Jumlah Bahan Baku Yang Dibutuhkan

Dalam hal jumlah bahan aku sekali produksi dapat dilihat pada tabel 7 dibawah ini :

Tabel 7. Jumlah Bahan Baku Yang Dibutuhkan Dalam Sekali Produksi

\begin{tabular}{|c|c|c|c|}
\hline No & Jumlah Bahan Baku & f & $\%$ \\
\hline 1 & $3 \mathrm{~m}^{3}$ & 1 & 33 \\
\hline 2 & $4 \mathrm{~m}^{3}$ & 0 & 0 \\
\hline 3 & $5 \mathrm{~m}^{3}$ & 2 & 67 \\
\hline & Jumlah & 3 & 100 \\
\hline
\end{tabular}

Sumber : Pengolahan Data 2018

Berdasarkan hasil wawancara dengan pemilik industri pada data tabel 9 tentang jumlah bahan baku yang dibutuhkan dalam sekali produksi 2 responden menjawab $5 \mathrm{~m}^{3}$ dan 1 responden menjawab $3 \mathrm{~m}^{3}$. Jadi rata-rata jumlah bahan aku yang dibuthkan sebanyak 3 sampai $5 \mathrm{~m}^{3}$ dalam sekali produksi dalam waktu 2 bulan. Jumlah tersebut tidak tetap, jumlah tersebut bisa bertambah sesuai kebutuhan produksi pada industri tersebut.

\section{c. Tenaga Kerja}

a) Status Tenaga Kerja

Status tenaga kerja dapat dilihat dalam tabel 8 dibawah ini : 
Tabel 8. Data Status Tenaga Kerja

\begin{tabular}{|c|l|r|r|}
\hline No & Status Tenaga Kerja & \multicolumn{1}{c|}{ f } & \multicolumn{1}{c|}{$\%$} \\
\hline 1 & Tetap & 1 & 33 \\
\hline 2 & Tidak tetap & 0 & 0 \\
\hline 3 & Tetap dan Tidak Tetap & 2 & 67 \\
\hline \multicolumn{2}{|c|}{ Jumlah } & 3 & 100 \\
\hline
\end{tabular}

Sumber : Pengelohan Data Tahun 2018

Berdasarkan hasil wawancara dengan pemilik industri pada tabel 10 mengenai status tenaga kerja sebanyak 1 responden menjawab mengunakan tenaga kerja tetap dan 2 responden menjawab mengunakan tenaga kerja tetap dan tidak tetap. Dari data diatas dapat disimpulkan bahwa industri mebel rata rata menggunakan tenaga kerja tetap dan tidak tetap.

b) Jumlah Tenaga Kerja

Berdasarkan

hasil

wawancara dengan pemilik industri dalam tabel 8 diapat disimpulkan jumlah tenaga kerja yang ada pada industri mebel. Jumlah tenaga kerja pada CV. Mekar Baru sebanyak 15 orang, jumlah tenaga kerja pada Yuriza perabot sebanyak 7 orang dimana 4 orang tenaga kerja tetap dan sebanyak 3 orang tenaga kerja tidak tetap dan jumlah tenaga kerja pada CV. Roland Kencana sebanyak 18 orang diamana sebanyak 10 orang adalah tenaga kerja tetap dan sebanyak 8 orang tenaga kerja tidak tetap.

c) Pendidikan dan Daerah Asal Tenaga Kerja Dalam pendidikan dan daerah asal tenaga kerja dapat dilihat pada tabel 9 dibawah ini :

Tabel 9. Data Pendidikan Tenaga Kerja

\begin{tabular}{|c|l|r|r|}
\hline No & Pendidikan & \multicolumn{1}{c|}{ f } & \multicolumn{1}{c|}{$\%$} \\
\hline 1 & SMP & 0 & 0 \\
\hline 2 & SMA/SMK & 3 & 100 \\
\hline 3 & S1 & 0 & 0 \\
\hline \multicolumn{2}{|l|}{ Jumlah } & 0 & 100 \\
\hline
\end{tabular}

Sumber : Pengolahan Data Tahun 2018

Berdasarkan hasil wawancara menjawab rata rata pendidikan dengan pemilik industri tentang asal dan pendidikan tenaga kerja pada terakhir tenaga kerja nya adalah SMA/SMk sederajat. industri mebel, 3 responden

Tabel 10. Data Asal Tenaga Kerja

\begin{tabular}{|c|l|r|r|}
\hline No & Asal Tenaga Kerja & \multicolumn{1}{|c|}{ F } & \multicolumn{1}{|c|}{$\%$} \\
\hline 1 & Dalam Kota & 0 & 0 \\
\hline 2 & Luar Kota & 3 & 100 \\
\hline \multicolumn{2}{|c|}{ Jumlah } & 0 & 100 \\
\hline
\end{tabular}

Sumber : Penglahan Data Tahun 2018 
Berdasarkan hasil wawancara dengan pemilik industri tentang asal tenaga kerja, 3 responden menjawab asal tenaga kerja kebanyakan dari luar. Dapat disimpulkan bahwa ratarata tenaga kerja berpendidikan SMA/SMK sederajat dan asal tenaga kerja pada industri mebel tersebut dari luar kota.

d) Keahlian Tenaga Kerja

Dalam hal keahlian tenaga kerja dapat dilihat pada tabel 11 dibawah ini :

Tabel 11. Data keahlian Tenaga Kerja

\begin{tabular}{|c|l|r|r|}
\hline No & Keahlian Tenaga Kerja & \multicolumn{1}{c|}{ f } & \multicolumn{1}{c|}{$\%$} \\
\hline 1 & Mahir & 2 & 67 \\
\hline 2 & Kurang Mahir & 1 & 33 \\
\hline 3 & Tidak Mahir & 0 & 0 \\
\hline \multicolumn{2}{|c|}{ Jumlah } & 3 & 100 \\
\hline
\end{tabular}

Sumber : Pengelohan Data Tahun 2018

Berdasarkan wawancara para pemilik industri dinilai dari dengan pemilik industri tentang hasil kerja atau produk yang keahlian yang dimiliki tenaga kerja, 2 responden menjawab keahlian yang dimiliki tenaga kerja sudah mahir dan 1 responden menjwab keahlian tenaga kerja kurang mahir. dihasilkan.

e) Pelatihan dan Penyuluhan Dalam hal penyuluhan dan pelatihan dapat dilihat pada tabel 12 Kemahiran tenaga kerja menurut

Tabel 12. Data Penyuluhan dan Pelatihan Tenaga Kerja

\begin{tabular}{|c|c|c|c|}
\hline No & Penyuluhan dan Pelatihan & $\mathrm{f}$ & $\%$ \\
\hline 1 & Ada & 0 & 0 \\
\hline 2 & Tidak Ada & 3 & 100 \\
\hline \multicolumn{2}{|r|}{ Jumlah } & 0 & 100 \\
\hline
\end{tabular}

Sumber : Pengolahan Data Tahun 2018

Berdasarkan hasil wawancara keahlian tenaga kerja yang dilakukan dengan pemilik industri tentang pelatihan dan penyuluhan terhadap keterampilan tenaga kerja, dalam hal pelatihan dan penyuluhan terhadap pihak terkait tidak ada.

f) Jumlah Jam Kerja Dalam hal jumlah jam kerja dapat dilihat pada tabel 13 dibawah ini :

Tabel 13. Data Jumlah Jam Kerja

\begin{tabular}{|c|c|c|c|}
\hline No & Jumlah Jam Kerja/hari & $\mathrm{f}$ & $\%$ \\
\hline 1 & Kurang Dari 8 Jam/Hari & 0 & 0 \\
\hline 2 & $8 \mathrm{Jam} /$ Hari & 2 & 67 \\
\hline 3 & Lebih Dari 8 Jam/Hari & 1 & 33 \\
\hline \multicolumn{2}{|r|}{ Jumlah } & 3 & 100 \\
\hline
\end{tabular}

Sumber : Pengolahan Data Tahun 2018 
Dari data tabel diatas dapat disimpulkan pada umumnya industri mebel di Kelurahan Pasia Nan Tigo bekerja 8 jam/hari.

\section{Industri Mebel Dari Segi Pemasaran dan Jangkauan Pelayanan}

a. Jenis Produksi dan Hasil Produksi

Berdasarkan hasil wawancara dengan pemilik industri tentang apa saja hasil produksi yang telah dibuat dan telah dipasarkan oleh pemilik idustri. Hasil produksi yang telah di buat dan dipasarkan bermacammacam, seperti kamat-set, kitchenset, lemari kantor dan sesuai permintaan komsumen. Rata-rata industri ini lebih banyak memproduksi kamar-set, lemari kantor dan kitchen-set.

b. Cara Pemasaran Dalam hal cara pemasaran dapat dilihat pada tabel 14 dibawah ini :

Tabel 14. Data Cara Pemasaran Hasil Produksi

\begin{tabular}{|c|l|r|r|}
\hline No & Cara Memasarkan & \multicolumn{1}{|c|}{ f } & \multicolumn{1}{c|}{$\%$} \\
\hline 1 & Memasarkan Langsung & 3 & 100 \\
\hline 2 & Melalui Perantara & 0 & 0 \\
\hline \multicolumn{2}{|c|}{ Jumlah } & 3 & 100 \\
\hline
\end{tabular}

Sumber : Pengolahan Data Tahun 2018

Berdasarkan dari hasil memasarkan langsung yaitu dari wawancara dengan pemilik industri mulut ke mulut atau rekomendasi mebel bagaimana cara pemasaran dari para konsumen tetap yang dilakukan, 3 responde menjawab dalam hal cara memasarkan mereka mengunakan cara memasarkan langsung kepada konsumen. Dalam hal ini cara

c. Pemasaran Media Online

Dala hal pemamikan media online dalam pemasaran dapat dilihat pada tabel 15 dibawah ini :

Tabel 15. Data Pemasaran Media Online

\begin{tabular}{|c|c|c|c|}
\hline No & Pemakaian Media Online Dalam Pemasaran & $\mathrm{f}$ & $\%$ \\
\hline 1 & Memakai Media Online & 1 & 33 \\
\hline 2 & Tidak Memakai Media Online & 2 & 67 \\
\hline & Jumlah & 3 & 100 \\
\hline
\end{tabular}

Sumber : Pengolahan Data Tahun 2018

Berdasarkan hasil wawancara dengan pemilik industri tentang penggunaan media online dalam pemasaran hasil produksi, dari tiga industri mebel hanya satu indstri yang mengguna kan pemasaran hasil produksi melalui media oline. d. Sebaran Hasil Produksi dan Biaya Angkut

Dalam hal sebaran hasil Produksi dan biaya angkut dapat dilihat dari tabel 16 dibawah ini : 
Tabel 16. Data Sebaran Hasil Produksi

\begin{tabular}{|c|c|c|c|}
\hline No & Sebaran Hasil Produksi & $\mathrm{f}$ & $\%$ \\
\hline 1 & Dalam Provinsi & 3 & 100 \\
\hline 2 & Luar Provinsi & 0 & 0 \\
\hline \multicolumn{2}{|c|}{ Jumlah } & 3 & 100 \\
\hline
\end{tabular}

Sumber : Pengolahan Data Tahun 2018

Berdasarkan hasil wawancara dengan pemilik industri tentang sebaran hasil poduksi, 3 responden menjawab sebaran hasil produksi industri mebel tersebar didalam provinsi khususnya Kota Padang. Dalam penghitungan biaya angkut hasil produksi para pemilik industri mebel tidak memiliki acuan yang baku dalam penghitungan biaya angkut.

e. Jarak Terjauh Pemasaran Hasil Produksi

Bedasarkan hasil wawancara dengan pemilik industri mebel tentang jarak terjauh pemasaran hasil produksi, dari ketiga pelaku industri mebel jarak terjauh pemasaran ratarata masih didalam provinsi, pengukurun dilakukan dengan menari garis lurus dari titik industri mebel ke titik terjauh pemasaran produksi. Jarak terjauh CV. Mekar Baru adalah Kapubaten Pasaman Barat lebih tepatnya Nagari Simpang Ampek dengan jarak $91 \mathrm{Km}$, jarak terjauh CV. Roland Kencana adalah Kabupaten Lima Puluh Kota lebih tepatnya Nagari Suliki dengan jarak $84 \mathrm{Km}$ dan jarak terjauh Yazira Perabot adalah Kabupaten Padang Pariaman lebih tepatnya Nagari Lubuk Alung dengan jarak $23 \mathrm{Km}$.

\section{PEMBAHASAN}

Industri Mebel Pada Faktor Produksi Dilihat Dari Segi Modal, Bahan Baku dan Tenaga Kerja

Dalam kemajuan suatu indusri sangat di depangaruhi faktorfaktor produksi seperti modal, bahan baku dan tenaga kerja. Berdasarkan hasil data yang telah diumpulkan, pada umumnya industri mebel di Kelurahan Pasia Nan Tigo termasuk golongan industri non ekstrakif beradsarkan bahan baku yang mana mengolah kembali hasil dari alam atau hasil dari produksi industri lain sedangkan menurut tenaga kerja industri mebel di Kelurahan Pasia Nan Tigo termasuk industri kecil menengah dimana jumlh tenaga kerja 5 sampai 20 orang.

a. Modal

Dari hasil penelitian yag dilakukan dapat disimpulkan bahwa modal sangat berpengaruh terhadap kegiatan industri. Dari ketiga industri mebel yang ada di Kelurahan Pasia Nan Tigo, dalam hal ketersdiaan modal CV. Mekar baru dan CV. Roland Kecana memiliki modal yang cukup dalam menjalankan proses produksi industri mebel. Sedangkan Yazira Perabot masih membutuhkan bantuan modal dalam pengembangan industri mebel nya, hal ini terbukti dengan pembatasan pesanan yang 
diproduksi dimana mereka hanya mengambil pesanan dalam skala kecil.

\section{b. Bahan Baku}

Dari hasil penelitian yang dilakukan dapat di simpulkan bahan baku merupakan bahan dasar dalam menggerakan industri karna bahan baku adalah bahan yang dijadikan suatu produk yang di produksi oleh industri mebel. Dalam hal bahan baku industri mebel di Kelurahan Pasia Nan Tigo rata-rata memdapatkan bahan baku dari daerah Kabupaten Padang Pariaman.

Dalam hal kebutuhan bahan baku untuk sekali produksi oleh industri mebel di Kelurahan Pasia Nan Tigo rata-rata 2 sampai $5 \mathrm{~m}^{3}$, dilihat dari segi biaya angkut bahan baku sudah termasuk kedalam biaya pembelian bahan baku. Dari ketiga industri mebel di Kelurahan Pasia Nan Tigo dalam mendapatan bahan baku mereka tidak kesulitan karna pasokan bahan baku dari milik pribadi maupun usaha somel kayu melakukan pengirim setiap 2 atau 3 bulan sekali.

\section{c. Tenaga Kerja}

Dilihat dari segi tenaga kerja yang ada di industri mebel di Kelurahan Pasia Nan Tigo umumnya berstatus tenaga kerja tetap dan ada tenaga kerja kontrak yang dibutuhkan apabila ada produksi yang mendesak dan banyak. Jumlah tenaga kerja tetap pada indsutri mebel di Kelurahan Pasia Nan Tigo rata-rata kurang dari 15 orang sedangkan tenaga kerja tidak tetap rata-rata kurang dari sepuluh orang yaitu.

Keahlian tenaga kerja pada industri mebel di Kelurahan Pasia Nan Tigo rata-rata sudah mahir dalam pengolahan bahan Baku, hal ini juga diiringi dengan pedidikan terkahir tenaga kerja yang rata-rata tamatan SMA/SMK Sederajat. Jumlah jam kerja pada ketiga industri mebel rata-rata 8 jam dalam sehari dan cara kerja pada ketiga industri mebel ini dilakukan secara manual dan modern.

Profil industri mebel pada faktor produksi yang dilihat dari segi modal, bahan baku dan tenaga kerja di Kelurahan Pasia Nan Tigo dalam hal modal bersumber dari modal proibadi. Dalam hal bahan baku pemilik industri meyatakan bahwa bahan baku yang ada untuk saat ini masih mencukupi dalam proses produksi. Pemilik industri mebel juga menyatakan bahwa dalam hal jumlah tenaga kerja berjumlah 5 sampai 20 orang. Industri mebel di Kelurahan Pasia Nan Tigo termasuk kedalam industri kecil menengah.

Hambatan Industri Mebel Dari Faktor Produksi yang Dilihat Dari Segi Modal, Bahan Baku dan Tenaga Kerja

Dalam suatu industri sangat dipengaruhi dari faktor produksi yaitu modal, bahan baku dan tenaga kerja dalam pengembangan nya. Dari ketiga faktor produksi tersebut ada 
salah satu atau semua faktor tersebut yang menghambatan sebuah industri untuk berkembang atau maju.

a. Modal

Dari data diatas hambatan modal yang dihadapi oleh industri mebel di Kelurahan Pasia Nan Tigo adalah memproduksi dalam skala besar sehigga diperlukan modal yang banyak. Industtri mebel ini hanya memiliki modal pribadi sehingga akan menghambat dalam perkembangan industri mebel tersebut.

b. Bahan baku Hambatan dalam hal bahan baku yang dihadapi oleh industri mebel di Kelurahan Pasia Nan Tigo adalah jarak sumber bahan baku dengan tempat produksi sehingga dalam pengiriman bahan baku sering terlambat tetapi hambatan tersebut tidak terlalu mengangu proses produksi

c. Tenaga kerja

Hambatan yang dihadapi industri mebel di Keluraha Pasia Nan Tigo adalah mencari tenaga kerja tetap yang mau bekerja sama dalam industri mebel ersebut. Hambatan lain yang dihadapi adalah mencari tenaga kerja kontrak dimana kesulitan nya tentang kontrak kerja.

\section{Industri Mebel Dilihat Dari Pemasaran dan Jangkauan Pelayanan}

a. Pemasaran

Hasil produksi mebel yang di pasarkan umumnya kamar set, kitchen set dan lemari perkatoran. Ketiga industri mebel tersebut langsung memasarkan hasil produksinya ke konsumen. Berdasarkan hasil wawancara dengan pemilik industri mebel diketaui cara pemasaran yang di lakukan adalah secara langsung atau mulut ke mulut, dimana para konsumen memesan langsung ke tempat industri mebel. Dari ketiga industri mlebel hanya satu indstri mebel yang memasarkan hasil produksinya ke toko yang menjual berbagai macam barang mebel. Dalam hal penggunaan media online dalam pemasaran hanya sau industri mebel yang menggunakan media online sebagai sarana pemasaran hasil produksi. Kegiatan pemasaran industri mebel pada umumnya juga tidak memiliki waktu tertentu.

Dari deskripsi diatas dapat disimpulkan bahwa pada umumnya pemasaran yang dilakukan oleh industri mebel di Kelurahan Pasia Nan Tigo ini dilakukan secara langsung, dan dalam hal pemasaran industri mebel di Keluarahan Pasia Nan Tigo ini tidak menemukan kesulitan karna pada umumnya pasar yang mengejar industri mebel tersebut.

b. Jangkauan Pelayanan Jangkauan pelayanan atau sebaran hasil produsi dari industri mebel di Kelurahan Pasia Nan Tigo pada umum nya beredar di Kota Padang dan kota atau kabupaten seitar Kota Padang. Dalam 
penentuan jangkauan pelayanan dapat dilihat menurut batas pasar nya yaitu batas riil, batas dalam, batas ideal (ullman dalam wahyudi, 2008). Dalam penentuan batas pasar tersebut telah diatur batas ideal adalah batas jangkauan terjauh dimana didapat dari hasil wawancara, batas riil adalah batas yang nyata harus dikuasi oleh industri tersebut dengan membagi jarak terjauh asal konsumen dengan batas pasar dalam hal ini ditetapka batas pasar nya adalah administrasi kecamatan Koto Tangah Sejauh 9 km yang seharusnya dapat dikuasai oleh industri dam batas dala adalah batas wilayah pasar yang jauh dari batas riil didapat dengan mengurangi batas dalam dan batas riil.

\begin{tabular}{lcc}
\multicolumn{2}{c}{ Berdasarkan } & penjelasan \\
diatas, berikut peta & jangkauan \\
pelayana industri mebel di
\end{tabular}
Kelurahan Pasia Nan Tigo. Pada gambar 1 dibawah dapat dilihat peta daerah jangkauan pelayanan dari $\mathrm{CV}$. Mekar Baru.

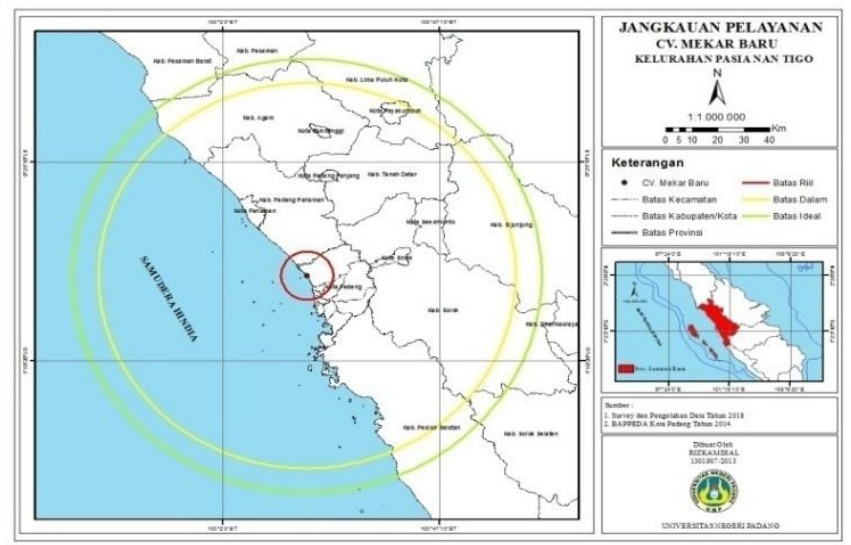

Gambar 1: Peta daerah jangkauan pelayanan dari CV. Mekar Baru

Pada gambar 1 diatas dapat dilihat derah jangkauan pelayanan dari CV. Mekar Baru, dimana batas ideal sejauh $91 \mathrm{Km}$ meliputi hampir semua wilayah Provinsi Sumatera Barat kecuali Kab. Dhamasraya, batas dalam sejauh $80,9 \mathrm{~km}$ meliputi sebagian wilayah Provinsi Sumatera Barat kecuali Kab. Solok Selatan,
Kab. Dhamasraya, Kab. Pasaman dan Kab Pasaman Barat dan batas riil sejauh 10,1 Km dimana meliputi beberapa kecamatan di Kota Padang.

Selanjut nya peta jagkauan pelayanan dari CV. Roland Kencana dapat dilihat pada gambar 2 dibawah ini : 


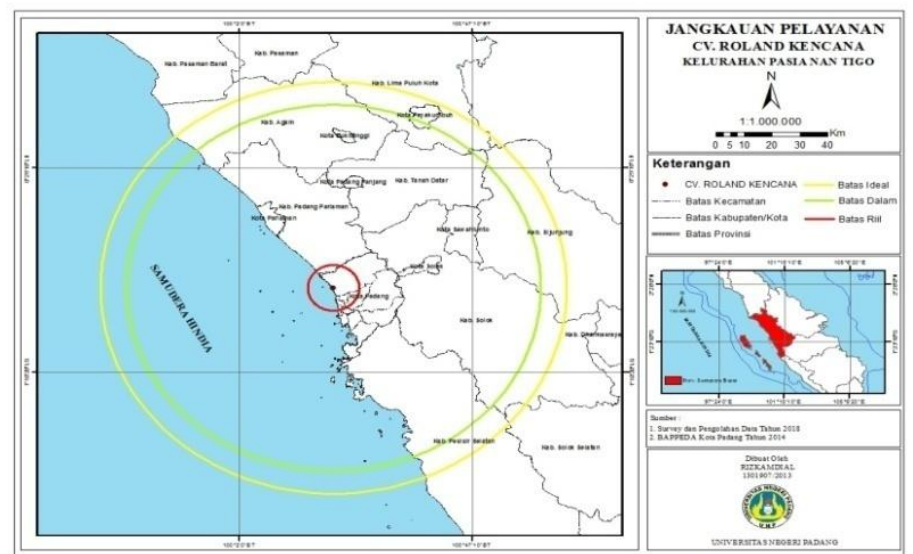

Gambar 2: Peta jangkauan pelayanan CV Roland Kencana

Pada gambar 2 diatas dapat dilihat daerah jangkauan pelayanan dari CV. Roland Kencana, batas ideal sejauh $84 \mathrm{~km}$ meliputi hampir semua wilayah Provinsi Sumatera Barat kecuali Kab. Pasaman, Kab. Pasaman Barat dan Kab. Dhamasraya, batas dalam sejauh 74,7 $\mathrm{Km}$ dimana meliputi sebagian wilayah Provinsi Sumatera Barat kecuali Kab. Pasaman Barat, Kab Pasaman, Kab Solok Selatan dan Kab. Dhamasraya dan batas riil sejauh 9,3 Km meliputi beberapa kecamatan di Kota Padang.

Selanjutnya peta jangkauan pelayanan Yazira Perabot dapat dilihat pada gambar 3 dibawah ini :

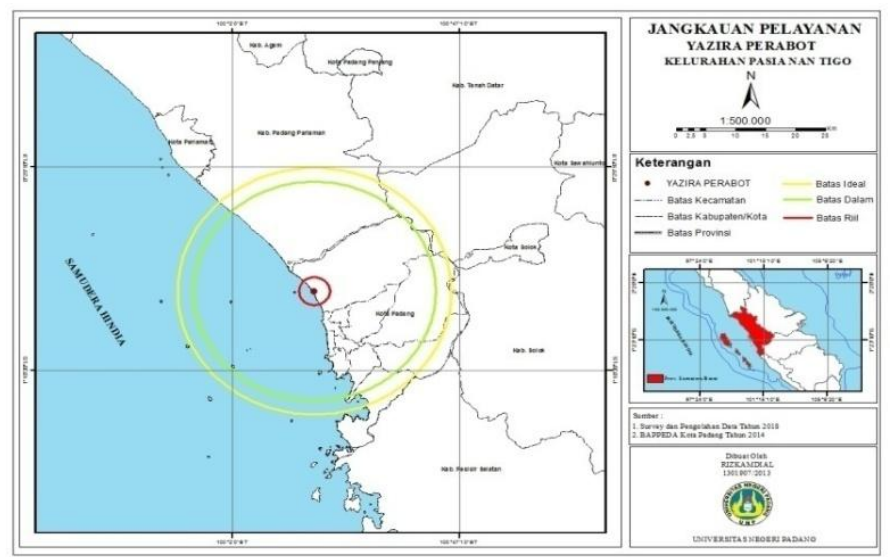

Gambar 3: Peta jangkauan pelayanan dari Yazira Perabot

Pada gambar 3 diatas dapat dilihat daeah jangkauan pelayanan dari Yazira Perabot, dimana batas ideal sejauh $23 \mathrm{Km}$ meliputi daerah Kota Padang, sebagian wilayah Kab. Padang Pariaman dan Kab Solok, bata dalam sejauh 20,4 km meliputi wilayah Kota Padang dan sebagian wilayah Kab. Padang Pariaman dan batas riil sejauh 2,6 Km meliputi sebagian wilayah Kecamatan Koto Tangah. Berdasarkan deskripsi data tentang jangkauan pelayanan maka dapat disimpulkan bahwa jangkauan pelayanan paling jauh dari ketiga industri mebel di kelurahan Pasia 
Nan Tigo adalah CV. Mekar Baru dimana batas idela nya sejauh 91 $\mathrm{Km}$, batas dalam nya $80,9 \mathrm{Km}$ dan batas riil 10,1 Km.

Dari ketiga peta jangkauan pelayanan masing-masing industri dapat dilihat pada gambar 4 dibawah ini perbandingan jangkauan pelayanan dari ketiga industri mebel di Kelurahan Pasia Nan Tigo.

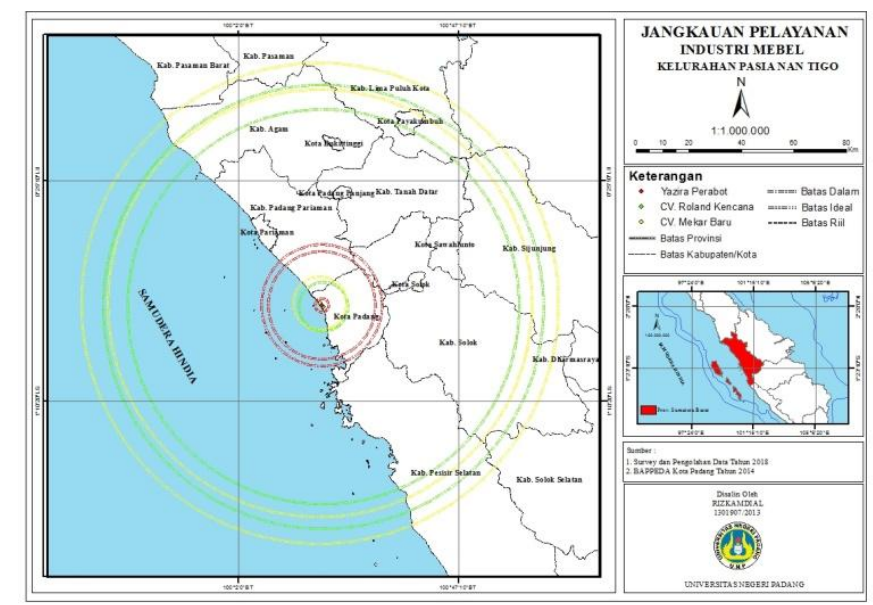

Gambar 4. Perbandingan Jangkauan Pelayan Industri Mebel Kelurahan Pasia Nan Tigo

\section{KESIMPULAN}

Berdasarkan hasil penelitian dan pembahasan tentang profil industri mebel di Kelurahan Pasia Nan Tigo diperoleh hasil sebagai berikut.

1. Profil industri mebel pada faktor produksi yang dilihat dari segi modal, bahan baku dan tenaga kerja, industri mebel di Kelurahan Pasia Nan Tigo dalam hal modal berasal dari modal pribadi. Dalam hal bahan baku pemilik industri meyatakan bahwa bahan baku yang ada untuk saat ini masih mencukupi dalam proses produksi.tenaga kerja yang ada sudah tetap dan sudah mahir. Industri mebel di Kelurahan Pasia
Nan Tigo termasuk kedalam industri kecil menengah.

2. Hambatan yang dihadapai oleh industri mebel pada faktor produksi yaitu modal, bahan baku dan tenaga kerja. Dari faktor modal hambatan yang dihadapi oleh pemilik industri mebel yaitu dalam produksi skala besar mereka memerlukan modal tambahan. Dalam hal bahan baku hambatan yang dihadapi oleh pemilik industri mebel adalah jarak asal bahan baku dengan tempat produksi dan membutuhkan waktu dalam pendistribusian bahan baku. Dari segi tenaga kerja hambatan yaang dihadapi oleh pemilik industri 
mebel dalam mencari sumber daya tenaga kerja tetap.

3. Pemasaran dan jangkauan pelayanan pada industri mebel di Kelurahan Pasia Nan Tigo. Dalam hal memasarkan hasil produksi industri mebel tidak memiliki kesulitan walaupun dalam pemanfaatan teknologi atau media online tidak signifikan. Dalam hal jangkauan pelayanan industri mebel di Kelurahan Pasia Nan Tigo rata-rata berada di dalam provinsi.

\section{DAFTAR PUSTAKA}

Bungi, Burhan. 2011. Metodologi Penelitian Jakarta. Kencana.

Badan Pusat Statistik, 2017. Perkembangan Perekonomian dalam Industri: BPS.

Cahyono, Bambang dan Adi, Sugiyo.1983. Manajemen Industri Kecil. Yogyakarta : Liberty.

Hartshorn, Truman A. (1980). Interpreting The City an Urban Geography. New York: John Wiley and Jons.

Kasmir.2014. Kewirausahaan. Jakarta : Rajawali Pers.

Manullang.1991. Mebel dan Interior Rumah. Jakarta: Erlangga.

Sudijono, Anas. 2011. Pengantar Statistik Pendidikan. Jakarta: PT Raja Grafindo Persaka.

Wahyudi, Tri. (2008). Jangkauan Pelayanan STTI I-Tech, STTIK Meridian, STMIK Perbanas, dan STMIK Widuri Tahun 2007 di Jakarta
Selatan. Skripsi Jurusan Geografi. FMIPA UI. Depok. 